\title{
よこ編における編成張力の一考察
}

$\begin{array}{llcll}\text { 工業技術院㵶維工業試験所 } & \text { 相 } & \text { 坂 } & & \text { 登（会員） } \\ & \text { 川 } & \text { 上 } & \text { 達 } & \text { 也 } \\ & \text { 新 } & \text { 藤 } & & \text { 忠 (会員) }\end{array}$

\section{Knitting Tension during Weft-Knitting}

\author{
Noboru Aisaka, Tatsuya Kawakami and Tadashi Shindo \\ Textile Research Institute of Japanese Government, Yokohama, Kanagawa-ken
}

\begin{abstract}
Knitting tension is an important quantity having a bearing on the loop length of the knit fabric and, therefore, on its quality and properties. A precise understanding of knitting tension is needed to fix the yarn strength and choose the method of pre-processing the yarn to be used.

Treating the yarn as a plasto-elastic material, this article discusses the generative mechanism of knitting tension and the effect of robbing back on the mechanism.

It is reasonable to think of knitting tension as frictional tension produced by scraping and bending yarn with the knitting elements.

When there is the additional tension of bending, knitting tension is affected by the diameter of yarn and the dimension of the knitting elements.

The larger the elastical and frictional coefficients of the yarn used, the larger the decrease in the knitting tension produced by robbing back.

The relation between knitting tension and the work done by robbing back has nothing to do with the knitting condition. The curve of that relation is conditioned by the yarn properties used.
\end{abstract}

(Received November 16, 1968)

\section{摘要}

目的よて編編成において，系を弾塑性材料として报い，編成張力の発生機構と，てれに対する robbing back 現象の影響について考察する。

成果 編成張力は，編成要素による系へのしでき作用によって付加された摩擦力であると考えるのが妥当である. 曲げによる付加張力を考えると，糸の太さ，編成要素の大きさが影響する。

R B 現象による編成張力の低下は，弾性係数，摩擦係数の大きい系ほど大きい。

編成張力一引き戻し仕事量曲線は，編成条件に関倸なく，系の物性に関連した曲線を描く。

（昭和 43 年 11 月 16 日受理）

\section{1. 緒言}

編成張力は, 編地を構成するループ長に, ひいては編 地の品質，物性に影響を及ぼす重要な因子である．同時 にまた，使用する原系の強伸度とか，その摩擦特性に関 連した糸処理をどのようにするのかを決める上にす，そ の適確な理解が強く要求されている.
最近, 動的状態での編成張力を測定した報告がなされ， 編成動作を解析するにあたって, 給糸張力とループ長と から推論していた時点から一歩前進したといえるが，編 成張力の発生についての考察はまだ不十分のようであ る. Garbaruk は, 針の編成動作による系の引き込み力 について解析したが，ての場合，対象とする系の質量が 非常に小さいため, 系の引き込み力だけでは編成張力を 
十分に説明することはできない，多くの垁験们研究にお いて, 系の摩擦特性がループ長や編成中の系切れなどに 影響するてとが明らかにされているてとから, 編成張力 を考察する上で, 摩擦による付加張力を無視することは できない。むしろ, 編成動作は編成要素（針やシンカー など）によって糸をしできながら引き込む動作であるか ら, 摩擦力が付加されるととによって編成張力が増加す ると考えるべきであろう.

摩擦力は系と編成要素との接触によって発生する力で あるが, 系の性質 (摩擦係数) はもとより, 接触面の状 態, 入口側の張力などによっても相異する. 一般に, 系 と円筒面との接触において, 入口側張力 $T_{I}$ と出口側張 力 $T_{0}$ の間には接触角を $\theta$ としてつぎの関係が導びかれ ている.

$$
\left(T_{0} / T_{I}\right)^{1-n}=1+(1-n) \cdot a \cdot\left(\rho / T_{I}\right)^{1-n} \cdot \theta \quad(n \neq 1)
$$

ここで, $\rho$ は円筒面の半径, $a$ は $[F / L]^{n-1}$ の次元を 屯つ常数, $n$ は摩擦力 $F$ と法圧力 $R$ との間に成り立つ $F=\mu R^{n}$ の関係における摩擦指数であって, 完全弾性体 間では $n=0.67$, 完全塑性体間では $n=1$ であると報告 されている。

(1) 式において, $n \rightarrow 1$ の場合には

$$
T_{0} / T_{I}=\exp \left(a \cdot\left(\rho / T_{I}\right)^{1-n} \cdot \theta\right)
$$

となり,さらに $n=1$ とおけば

$$
T_{0} / T_{I}=\exp (\mu \theta)
$$

となって, Amonton の式となる.

各種の紡績系やフィラメント系を用いた垁験結果によ ると, $n$ は $0.75 \sim 0.98$ の值をとるから, 編成張力を考 えるにあたっては（1）式を用い杖なららいが，系に 潤滑剂を添加した場合には $n \geq 0.89$ となり (2) 式に より考察を進めても十分である.さらに，マクロな扱い をする場合には（3）式によって入・出口の張力関係を 求めてもよいであろう.

編成張力は（2）式あるいは（3）式に基づいて縻擦 により付加された力として求めるてとが可能であるが, 綃成道程においては，給系侧から系を引き込むだけでは

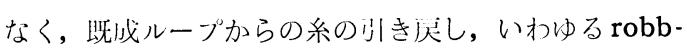
ing back 現象 (以下, RB鬥象之記す) が起とり, こ のために練成張力が低下する。つまり, 編成動作の進行 に上もなって，針が緗成点在通過した後では，それまで の針の運動方向が変わり, 編成域出口に向かって張力は 低下していく，てのため, 編成張力の最大值は, 必ずし 屯接触角が最大となる編成点に針が来たときに生じるの
ではなく，給系口側にずれた位置にあることが実験的に も確かめられている.

本報では，系を弾塑性体として扱い，編成動作による 引き込みと, R B 現象による影響とに関連して, 編成張 力を現象論的に考察する.

\section{2. 編成過程と編成張力}

\section{1 編成過程}

よて編における編成動作は, 針がステッチカムの作用 を受けて下降（後退）運動を行ない，それにつれてフッ ク中に供給された糸をオールドループの中に引き込んで ニューループを形成する動作であり，系の折り曲げと引 き込みが同時に行なわれる. このため, 系は編成要素に よるしごきを受けて摩擦力が付加され, 針が編成点に近 づくにつれて編成張力は大きくなる，また，編成点を通 過後, 針が上昇 (前進) 運動すれば, 系の伸長は回復し 張力は低下する.

いま, 編成域に扔いて, オールドループとニュールー プの接触, 屈曲を無視し, 各編成要素 $\mathrm{N}, \mathrm{S}$ によって曲 げられた系の状態を図示すると第 1 図になる. 系と編成

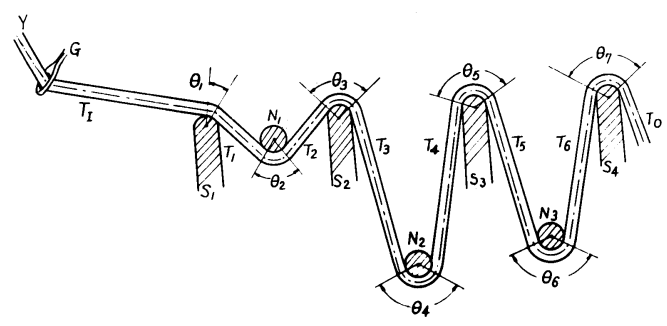

$$
\begin{array}{lll}
N: \text { 針 } & S: \text { シンカ } & G: \text { 給糸口 } \\
Y: \text { 系 } & T: \text { 張力 } & \theta: \text { 接触角 }
\end{array}
$$

（第 1 図）編成域に求ける系之編成要素之の関係 要素之の接触角を $\theta i$, 各区間における系張力（編成張 力）を $T_{i}$ とすれば（2）式あるいは（3）式により, 給系張力 $T_{I}$, 系之編成要素之の摩擦係数 $\mu_{i}\left(\rho_{i}, T_{i}\right)$, 編成要素の曲率半径 $\rho_{i}$ とからつぎの関係がなりたつ.

$$
T_{i}=f_{1}\left(T_{I}, \mu_{i}, \rho_{i}, \theta_{i}\right)
$$

また， R B 現象を考慮すれば, 編成域仙口における系張 力 $T_{0}$ が関係するから

$$
T_{i}=f_{\mathbf{2}}\left(T_{I}, T_{0}, \mu_{i}, \rho_{i}, \theta_{i}\right)
$$
上なる。

$\mathrm{R} B$ 现象による編成張力の变化については 3 章で考察 することとし，乙こでは，系の引き込み㭙のしできによ る摩擦力の増加, つまり, 給系点から編成点までの間に おける編成張力を考える. また, 各編成要素によって系 に付加される張力を（2）式供基づいて考えると, 各区 
間における張力 $T_{i}$ を個々に求めなければならず, 計算 が複雑になるから（3）式つまり Amonton の式が成 り立つ場合として考察する。

\section{2 針位置之接触角}

以上の仮定に立って考察するにあたって, 第 2 図に示 す編成域のモデルを考える.すなわち, 糸断面は半径 $d$ の円であり, 曲げによっても形状に変化はないとする. また, 針ック部およびシンカーの系と接触する部分の 断面屯円形であり, それぞれの半径を $r_{2}, r_{1}$ とする.

2-1図

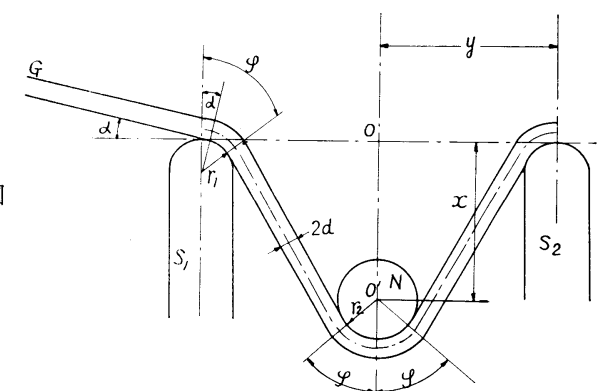

$2-2$ 図

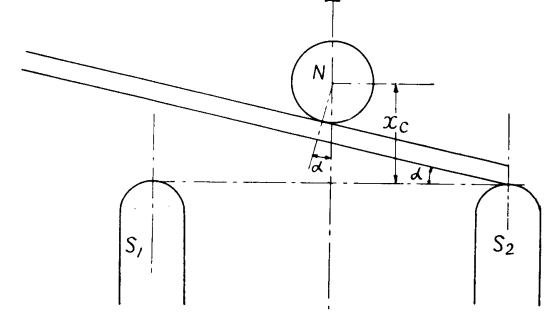

2-3 図

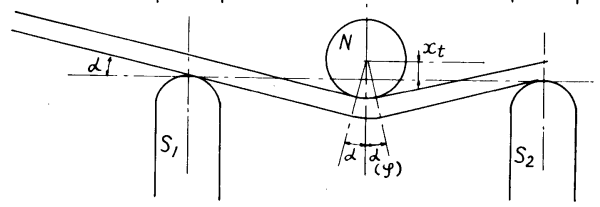

（第 2 図） 編成域のモデル I

いま，1本の針 $N$ で編成動作が行なわれるとすれば， 編成張力 $T_{2}$ は $(3)$ 式の関係加ら給糸張力 $T_{I}$ の関数 として求められる.

$$
T_{2}=T_{I} \exp \left(\mu\left(\theta_{1}+\theta_{2}\right)\right)
$$

ただし， $\theta_{1}, \theta_{2}$ は第 1 図に示した位置における糸之編 成要素との接触角, $\mu$ は摩擦係数で位置や張力に関係な く一定としたものである. 接触角 $\theta$ は針の下降に伴って 大きくなり, 針の位置により定まるから, 給系張力 $T_{I}$ が一定であれば, 編成張力 $T_{2}$ は針の位置の関数として 求められる.

第 2-1 図において, シンカー $S_{1}, S_{2}$ の上面を結ぶ直 線を $y$ 軸にとり,その中点 0 を通り $y$ 軸に垂直な座標を $x$ 軸として, 下向きに正とする．針の中心 $0^{\prime}$ はつねに $x$ 饽上にあるから, その座標值 $x$ で針の位谓を示すこと
にする.

針間隔を $2 y$ とし, また, 給系口 $G$ と針 $N$ との距離 $\overline{G N}$ は $y$ に比べて十分大きく，供給された糸が $y$ 軸とな す的 $\alpha$ は針の位置 $x$ に関係なく一定であるとする，第 2-1 図から变数 $x$ (針位置) と $\varphi$ (角) の間につぎの関 係が成り立つ.

$$
x=d+r_{1}+y \tan \varphi-\left(2 d+r_{1}+r_{2}\right) \sec \varphi \cdots
$$

これを解いて $\varphi$ を求めると

$$
\left.\begin{array}{c}
\varphi=\sin ^{-1} g(x) \\
g(x)=\left(R y+X \sqrt{y^{2}+X^{2}+R^{2}}\right) /\left(y^{2}+X^{2}\right) \\
\quad X=x-d-r_{1} \\
R=2 d+r_{1}+r_{2}
\end{array}\right\}
$$

となる、針が系と接触し始める位置 $x_{c}$ は第 2-2 図よ り， $\varphi=-\alpha$ として求まるから, $x_{c}=d+r_{1}-y \tan \alpha-\left(2 d+r_{1}+r_{2}\right) \sec \alpha \cdots$ また，さらに針が下降し，糸がシンカー $S_{1}$ と接触する ときの針位置 $x_{t}$ は，第 2-3 図より $\varphi=\alpha$ であるから，$$
x_{t}=d+r_{1}+y \tan \alpha-\left(2 d+r_{1}+r_{2}\right) \sec \alpha \cdots
$$

したがって， $x_{c}<x \leq x_{t}$ における針と系との接触们 $\theta_{2}$ は, 第 2-3 図の関係加ら,

$$
\theta_{2}=\varphi+\alpha
$$

また, $x_{t}<x \leq x_{\max }(=h:$ カムセット) においては, 系とシンカーおよび針との接触角 $\theta_{1}, \theta_{2}$ は第 2-1 図に より, $\theta_{1}=\varphi-\alpha, \theta_{2}=2 \varphi$ で与えられ, 給系点からの 全接触角 $\theta$ は

$$
\theta=\theta_{1}+\theta_{2}=3 \varphi-\alpha
$$

となる.（6 ),（8)，(12),（13）式加ら, 針 1 本で編 成動作が行なわれるときの編成張力の変化が求められる (第 4 図参照).

つぎに，針 $N_{1}$ が編成点に達する前 $\left(x_{1}<x_{\max }\right)$ ， 後続の針 $N_{2}$ が系と接する場合を考える．いま，力ム角 度を $\gamma$ とすれば, 針 $N_{1}, N_{2}$ の位置 $x_{1}, x_{2}$ の間につぎ の関係が成り立つ.

$$
x_{1}=x_{2}+2 y \tan \gamma
$$

したがって， $x_{1}=x_{c}+2 y \tan \gamma$ になったとき，針 $N_{2}$ が系に接する. $x_{t}+2 y$ tan $\gamma \geq x_{\max }$ であれば, $x_{c}+$ $2 y \tan \gamma<x_{1} \leq x_{\max }$ に扔いて, 系とシンカー $S_{1}$ との 接触角 $\theta_{1}$ および給系位置からの全接触角 $\theta$ は, 第 3-1 四より

$$
\begin{aligned}
\theta_{1} & =\varphi_{1}+\varphi_{2} \\
& =\sin ^{-1} g\left(x_{1}\right)+\sin ^{-1} g\left(x_{2}\right) \\
\theta & =\left(\varphi_{1}+\varphi_{1}\right)+\left(\varphi_{1}+\varphi_{2}\right)+\left(\varphi_{2}+\alpha\right) \\
& =3 \varphi_{1}+2 \varphi_{2}+\alpha \quad \ldots \ldots \ldots \ldots \ldots \ldots \ldots \ldots \ldots \ldots \ldots
\end{aligned}
$$



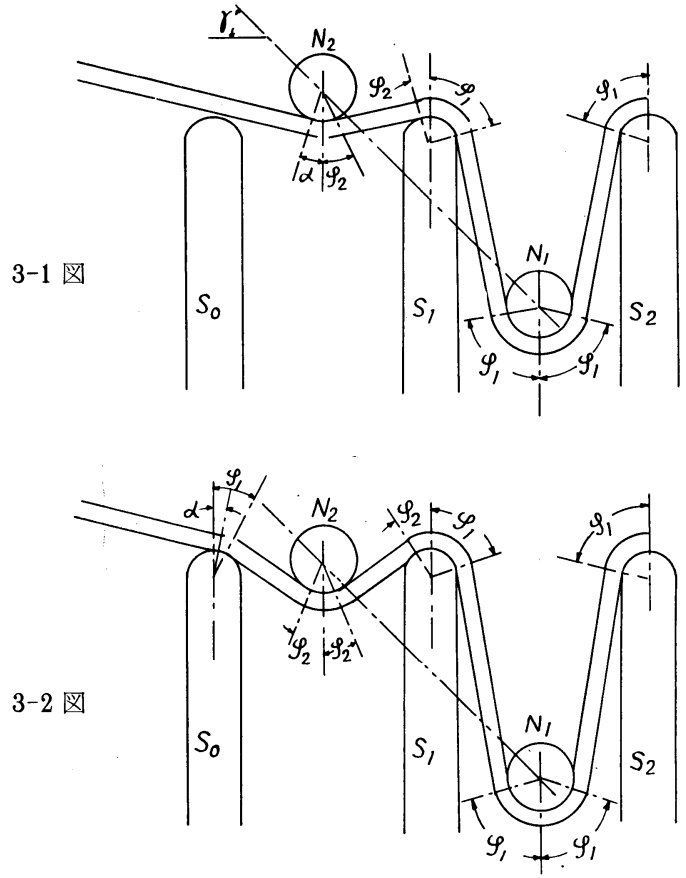

（第 3 図）編成域のモデル II

また, $x_{t}+2 y \tan \gamma<x_{\operatorname{mr}} \mathrm{x}$ であれば, $x_{1}=x_{t}+2 y$ $\tan \gamma$ において糸はシンカー $S_{0}$ と接触するから $x_{t}+$ $2 y \tan \gamma<x_{1} \leq x_{\max }$ において, 全接触角 $\theta$ は第 $3-2$ 四より

$$
\begin{aligned}
\theta & =\left(\varphi_{1}+\varphi_{1}\right)+\left(\varphi_{1}+\varphi_{2}\right)+\left(\varphi_{2}+\varphi_{2}\right)+\left(\varphi_{2}-\alpha\right) \\
& =3 \varphi_{1}+4 \varphi_{2}-\alpha \quad \ldots \ldots \ldots \ldots \ldots \ldots \ldots \ldots \ldots \ldots \ldots \ldots \ldots \ldots \ldots \ldots \ldots \ldots \ldots
\end{aligned}
$$

となる。

3 本以上の針が重なって編成する場合についても同様 にして針位置と接触角の関係が求められるが，いずれに しても計算はかなり面倒になる．したがって，簡便法之

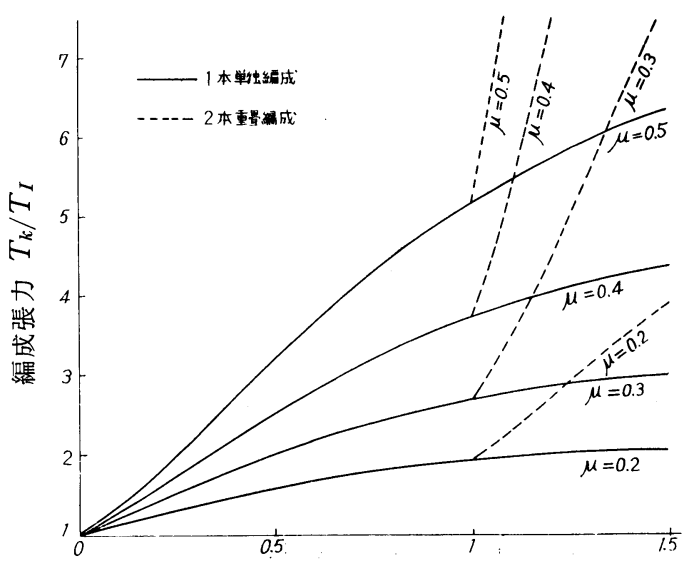

針”位 置 $x / y$

（第 4 図）針位置と編成張力の関係
して，系および編成要素の太さ，厚さを無視すれば( 8 ) 式の角 $\varphi$ は

$$
\left.\begin{array}{l}
\varphi \fallingdotseq \varphi^{\prime}=\tan ^{-1}(x / y) \\
g^{\prime}(x)=x / \sqrt{y^{2}+x^{2}}
\end{array}\right\}
$$

となり, 計算が容易になる。第 4 図は, この近似計算に より, 摩擦係数をパラメーターとして針位置に対する編 成張力の值を求め示したものである.

2.3 曲げによる付加張力を考慮する場合

(2), ( 3 )式の誘導にあたって, 系の直径 $2 d$ は円筒 の半径 $\rho$ に比べて微小であるとして, 曲げによる付加張 力は無視されている.しかし，編成要素の断面を円筒之 みなしたとき，その半径 $r$ は糸の太さ $2 d$ を無視できる ほどに大きくはない，したがって，編成張力を考える場 合, 系を曲げるために要する力を考察しておく必要があ ろう.

第 5 図において, 系を弾完全塑性体とみなし, その断 面は円形で曲げによる変形はないものとする，いま，微

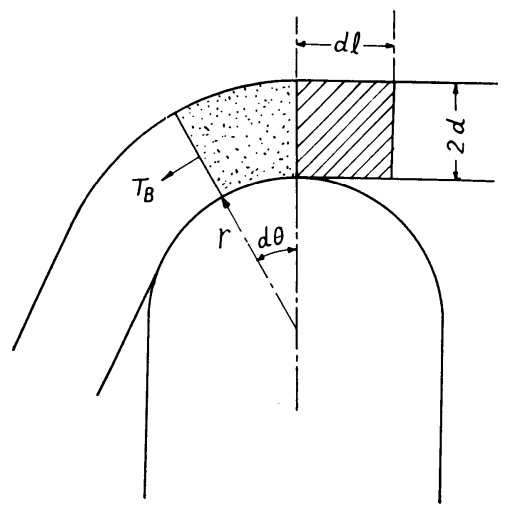

（第 5 図）引き込みによる曲げ

小長さ $d l$ の糸区間を円筒面に引き込んで角 $d \theta$ に曲げ るときの曲げ仕事 $M \cdot d \theta$ が, 付加張力 $T_{B}$ in によっ て $(r+d) \cdot d \theta$ だけ引き込まれる間になされたとすれ ば,

$$
T_{B \text { in }} \cdot(r+d) \cdot d \theta=M \cdot d \theta
$$

ここで, $M$ は曲げモーメントである. 半径 $d$ の円形断面 における全塑性曲げモーメントは, 糸の降伏張力を $T_{e}$ として,

$$
M=\frac{4}{3 \pi} \cdot d: T_{e}
$$

であるから（19），(20）両式から付加張力 $T_{B}$ in は,

$$
T_{B \text { in }}=\frac{4}{3 \pi} \cdot \frac{d}{r+d} \cdot T_{e}
$$

で与えられる，てれが円筒面入口で付加されるから，出 口においては（3）式により 


$$
T_{B \text { out }}=T_{B \text { in }} \cdot \exp (\mu \theta)
$$

となる，さらに，系は円筒面出口において曲げ戻しをう け，乙の曲林戻しによる付加張力む近似的に $T_{B}$ in $に$ 等 しいと考えられるから, 結局, 曲げによる付加張力 $T_{B}$ は

$$
\begin{aligned}
T_{B} & =T_{B \text { in }}+T_{B \text { cut }} \\
& =T_{B \text { in }}(1+\exp (\mu \theta)) \\
& =\frac{4}{3 \pi} \cdot \frac{d}{r+d} \cdot T_{e}\left(1+\exp \left(\begin{array}{ll}
\mu & \theta
\end{array}\right)\right)
\end{aligned}
$$

となる。（23）式より, 編成要素の形状が小さい（細ゲ 一ジ）場合, より太い系の場合, および降伏張力の大き い系の場合には, 曲げによる付加張力は大きくなること がわかる.

しかしながら，系断面は必ずしも円形でなく，仮にま っすぐな状態で断面円形とみなしても，曲げた状態では 円形がくずれ，さらに（19）式での曲げ仕事は，糸の引 き込みにのみついやされるのではなく, 系を構成する繊 維開のずれとかねじりなどにあついやされる，また，系 によっては降伏張力すら明らかでない場合むあり（23） 式から曲げによる付加張力を算出しても, 実際とかなり 離れた值が得られることになろう。

2.2 抢よび 2.3 の考察に基づき, 編成張力は定性的に 調べることはできるが，定量的に把握するためには実験 により調べなければならない。

\section{Robbing Back 現象による編成張力の} 変化

編成域中における針の運動はカムによって規制される が, 針が力ムの踏をはずれたあとはカムからの拘束力が なくなり，針の重さと針みぞに対する摩擦力とその針が 保持するループの張力とのつりあい関係によって運動軌 跡をかき, 新たな平衡状態に達してから走行位置へと移 ってゆく.

第 6 図は, 編成点K.P.以降の編成域における系の座曲

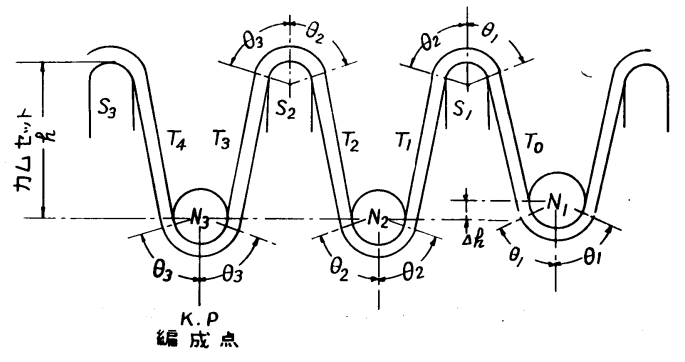

（第 6 図）編成点以降の編成域における 系之編成要素の関係
状態を示した図である．針 $N_{1}$ が踏をはずれて $\Delta h$ だけ 移動したあとの系張力 $T_{0}$ は, 当然, 針 $N_{1}$ が踏にかか

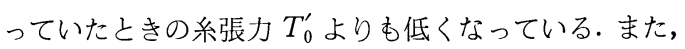
針 $N_{1}$ が $\Delta h$ だけ移動したために, 系とシンカー面との 接触角 $\theta_{1}$ あ変化して小さくなる. 乙の張力 $T_{0}$, 接触 角 $\theta_{1}$ の低下により，針 $N_{1}$ が保持しているループから 編成点に向かって張力変化の伝播および系の移動が起て り, 編成張力が低下しループ長も短くなる。乙れが R B 現象である.

この R B 現象による張力低下と系移動を第 6 図の状態 で解析するのは困難であるから，つぎの仮定を㧈いて考 える.

イ）系，針およびシンカーの太さ，厚さは無視し，系 之編成要素之の接触角は編成要素相互位置加ら幾 何学的に求めた值とする.

ロ）オールドループとニューループの接触は無視す る.

八）系は完全にたわみやすく，曲げ岡性が働かないも のとする.

二）系区間の張力は Amonton の式 (3) に従い, 系々編成要素との摩擦係数は定值をとるものとす る.

以上の仮定のむとに，第 6 図を第 7 図のように書きな

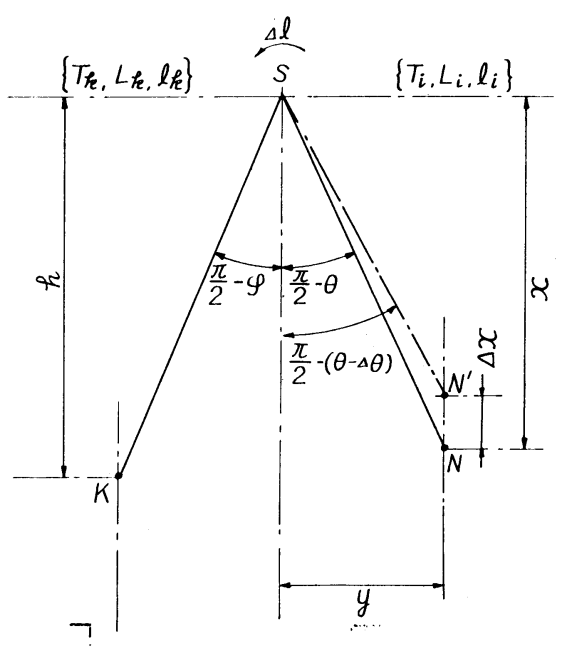

（第 7 図）第 6 図のモデル

おす. 両図に抢ける記号の対応は, $S_{1}: S, N_{1}: N$, $N_{2}: K, T_{0}: T_{i}, T_{1}: T_{k}, \theta_{1}: \theta, \theta_{2}: \varphi$ である. さらに, 第 6 図に打いて,

$$
T_{3}=T_{1} \exp \left(\mu\left(3 \theta_{2}+\theta_{3}\right)\right)
$$

であるから， $\varphi=4 \theta_{2}+\theta_{3}$ 之考えれば，第 7 図の $T_{k}$ は 第 6 図の $T_{3}$ 之対応づけで考えることができる. 
いま，糸区間 $S N, S K$ の張力 0 における長さを $l_{i}$, $l_{k}$, 張力 $T_{i}, T_{k}$ における長さを $L_{i}, L_{k}$ として, 考察 の範囲では糸張力は糸の伸びに比例すると考える.する 之, 系の引張弾性係数を $E$ とすればつぎの関係が成り立 ว.

$$
\begin{aligned}
T_{i} & =E \cdot\left(L_{i}-l_{i}\right) / l_{i} \\
T_{k} & =E \cdot\left(L_{k}-l_{k}\right) / l_{k} \\
T_{k} & =T_{i} \cdot \exp \{\mu(\theta+\varphi)\} \\
L_{i} & =\sqrt{x^{2}+y^{2}} \\
L_{k} & =\sqrt{h^{2}+y^{2}} \\
x & =y \cdot \tan \theta
\end{aligned}
$$

ただし， $\mu$ は糸と編成要素との摩擦係数， $y$ は針とシン カーの中心間距離（針間隔の $1 / 2$ ), $h$ はカムセット, $x$ は針 $N$ が踏をはずれたあとのシンカー面からの距離で $h \geqq x \geqq x_{\min }\left(x_{\min }\right.$ はカム形状によって定まる）の範网 にある。

針 $N$ が $N^{\prime}$ に移って， $x$ が $\Delta x$ だけ変化したために, 接触们 $\theta$, 張力 $T_{i}, T_{k}$, 系長 $L_{i}, l_{i}, l_{k}$ が変化したと する. ここで $l_{i}$ と $l_{k}$ の変化は, 張力変化によって止じ た正味糸長の移動つまり R B 归象による引き㞍し糸長老 意味し， $l_{i}$ と $l_{k}$ の間で等量の糸長 $\Delta l$ が授受される。 なお， $x$ が変化しても， $S$ と $K$ の位置は変化しないか ら， $\varphi$ および $L_{k}$ は一定である.

上にあげたそれぞれの変化量が微小であるとすれば， (24) 式より

$$
\begin{aligned}
& \Delta T_{i}=E \cdot\left(1 / l_{i} \cdot \Delta L_{i}-L_{i} / l_{i}^{2} \cdot \Delta l\right) \\
& \Delta T_{k}=E \cdot L_{k} / l_{k}^{2} \cdot \Delta l \\
& \Delta T_{k}=\exp \{\mu(\theta+\varphi)\} \cdot \Delta T_{i}+T_{k} \cdot \mu \cdot \Delta \theta \\
& \Delta L_{i}=x / L_{i} \cdot \Delta x \\
& \Delta x=y \cdot \sec ^{2} \theta \cdot \Delta \theta
\end{aligned}
$$

となる.乙れを整理して $\Delta x$ に対する張力変化 $\Delta T_{k}$ お よび系の移動量 $\Delta l$ の関係を求めると,

$$
\frac{\Delta T_{k}}{\Delta x}=\frac{E / l_{i} \cdot x / L_{i} \cdot \exp \{\mu(\theta+\varphi)\}+T_{k} \cdot \mu \cdot \cos ^{2} \theta / y}{1+\left(l_{k} / l_{i}\right)^{2} \cdot L_{i} / L_{k} \cdot \exp \{\mu(\theta+\varphi)\}}
$$

$\frac{\Delta l}{\Delta x}=\frac{x /\left(l_{i} \cdot L_{i}\right) \cdot \exp \{\mu(\theta+\varphi)\}+T_{k} / E \cdot \mu \cdot \cos ^{2} \theta / y}{L_{k} / l_{k}^{2}+L_{i} / l_{i}^{2} \cdot \exp \{\mu(\theta+\varphi)\}}$

となる.（26）（27）式から, 編成張力 $T_{k}$ が大きいと
きほよ゙，針の一定移動に対する編成張力の低下および糸 のやき戻し昷は大きくなるととがわかる。

また，乙れら雨式において，E之 の变数と独泣である.したがって変化星 $\Delta T_{k} / \Delta x, \Delta l$ $/ \Delta x$ を $E$ と の関数

$$
\frac{\Delta T_{k}}{\Delta x}(E, \mu) ; \frac{\Delta l}{\Delta x}(E, \mu)
$$

として考えることができる. まず， $\mu=$ 一定として $E$ に ついて（26），(27）式を書きかえると，

$$
\begin{aligned}
& \frac{\Delta T_{k}}{\Delta x}(E)=A_{E} \cdot E+B_{E} \\
& A_{E}=\frac{x /\left(l_{i} \cdot L_{i}\right) \cdot \exp \{\mu(\theta+\varphi)\}}{1+\left(l_{k} / l_{i}\right)^{2} \cdot L_{i} / L_{k} \cdot \exp \{\mu(\theta+\varphi)\}} . \\
& B_{E}=\frac{T_{k} \cdot \mu \cdot \cos ^{2} \theta / y}{1+\left(l_{k} / l_{i}\right)^{2} \cdot L_{i} / L_{k} \cdot \exp \{\mu(\theta+\varphi)\}} . \\
& \frac{\Delta l}{\Delta x}(E)=A_{H^{\prime}}^{\prime}+B_{W^{\prime}}^{\prime} / E \\
& A_{\boldsymbol{E}^{\prime}}^{\prime}=\frac{x /\left(l_{i} \cdot L_{i}\right) \cdot \exp \{\mu(\theta+\varphi)\}}{L_{k} / l_{k}^{2}+L_{i} / l_{i}^{2} \cdot \exp \{\mu(\theta+\varphi)\}} \\
& B_{F^{\prime}}^{\prime}=\frac{T_{k} \cdot \mu \cdot \cos ^{2} \theta / y}{L_{k} / l_{k}^{2}+L_{i} / l_{i}^{2} \cdot \exp \{\mu(\theta+\varphi)\}}
\end{aligned}
$$

冬変数の定義加ら, $A_{E}>0, B_{E}>0, A_{E}^{\prime}>0, B_{E}^{\prime}>$ 0 であるから，系の摩擦係数が等しい場命には，引張弾 吽係数の大きい系ほど R B現象による張力の低下は大き いが，引き㡶される系の長さは短くなる，ただし（28）， (29）式において各係数中の $T, l$ に $E$ が陰関数として 含まれるから，必ずしもこのような簡単な関係で表わさ れないであろう。

つぎに， $E=$ 一定として, $\mu$ の相違について考える. この場合 $(25)-$ (ii) 式の関係加ら, $\Delta l / \Delta x(\mu)$ は $\Delta T_{k} / \Delta x(\mu)$ と同じ変化をするから $(26)$ 式の変化を調 べるだけでよい.（26）式を $\mu$ の関数として書きなおす 亡,

$$
\begin{aligned}
& \frac{\Delta T_{k}}{\Delta x}(\mu)=\frac{A_{\mu} \cdot \exp \{\mu(\theta+\varphi)\}+B_{\mu} \cdot \mu}{1+C_{\mu} \cdot \exp \{\mu(\theta+\varphi)\}} \\
& A_{\mu}=E / l_{i} \cdot x / L_{i}>0 \\
& B_{\mu}=T_{k} \cdot \cos ^{2} \theta / y>0 \\
& C_{\mu}=\left(l_{k} / l_{i}\right)^{2} \cdot L_{i} / L_{k}>0
\end{aligned}
$$

このままでは， $\mu$ の変化による影響を推定しにくいから （30）式を $\mu$ で微分して変化の様子を浻べる.すると, （31）式となる.（31）式右辺の分母はつねに正であるか ら(31)式の符号は分子の正負によって決まる. こてで,

$$
\frac{\partial}{\partial \mu} \cdot \frac{\Delta T_{k}}{\Delta x}(\mu)=\frac{\left[A_{\mu}(\theta+\varphi)+B_{\mu} \cdot C_{n}\{1-\mu(\theta+\varphi)\} \exp \left\{\mu\left(\theta+\varphi^{\prime}\right\}+B_{\mu}\right.\right.}{\left[1+C_{\mu} \cdot \exp \{\mu(\theta+\varphi)\}\right]^{2}}
$$


分子だけをとりだしてまとめると

$$
\begin{aligned}
G & =\left\{A_{\mu} /\left(B_{\mu} \cdot C_{\mu}\right)-\mu\right\}(\theta+\varphi)+1 \\
& +\exp \{-\mu(\theta+\varphi)\} / C_{\mu} \quad \ldots \ldots \ldots . . .
\end{aligned}
$$

（32）式右辺の第 2，3 項は正であるから

$$
A_{\mu} /\left(B_{\mu} \cdot C_{\mu}\right)>\mu
$$

は $G$ が正であるための十分条件である， $\left(30^{\prime}\right),\left(30^{\prime \prime}\right)$, $\left(30^{\prime \prime \prime}\right)$ 式と $y=L_{i} \cos \theta, T_{k}=E\left(L_{k}-l_{k}\right) / l_{k}$ の関係加 ら

$$
A_{\mu} /\left(B_{\mu} \cdot C_{\mu}\right)=x / y \cdot L_{k} /\left(L_{k}-l_{k}\right) \cdot l_{i} / l_{k} \quad \cdots \quad(34)
$$

となる．第 7 図および各変数の定義から， $x \fallingdotseq h$ におい ては $l_{i} / l_{k}>1$ ，また， $x \fallingdotseq x_{\min }$ においてす， $l_{i} / l_{k}$ はたか だか $1 / 2$ くらいである. また, $x / y>1, L_{k} /\left(L_{k}-l_{k}\right) \gg 1$ であるから, 考察の範囲では $A_{\mu} /\left(B_{\mu} \cdot C_{\mu}\right)>1$ と考えて 上い，一方，摩擦係数 $\mu$ は $1 \geqq \mu \geqq 0$ であり，普通，系 之金属閒の摩擦係数は 0.6 以下であるから（33）式が成 り立つ.したがって，

$$
\frac{\partial}{\partial \mu} \cdot \frac{\Delta T_{k}}{\Delta x}(\mu)>0
$$

つぎに（31）式で $\mu=0$ とおけば,

$$
\left.\frac{\partial}{\partial \mu} \cdot \frac{\Delta T_{k}}{\Delta x}(\mu)\right|_{\mu=0}=\frac{A_{\mu}(\theta+\varphi)+B_{\mu} \cdot C_{\mu}+B_{\mu}}{\left(1+C_{\mu}\right)^{2}}>0
$$

また（31）式に扔いて， $\mu$ の増大につれて分子より分 母名急速に增大するから（31）式は渐減する（35), （36）式により（31）式は単調減少関数, したがって, 元の関数 $\Delta T_{k} / \Delta x$ は単調増加関数となる.

(30) 式で $\mu=0$ とおけば,

$$
\begin{aligned}
\left.\frac{\Delta T_{k}}{\Delta x}(\mu)\right|_{\mu=0} & =\frac{A_{\mu}}{1+C_{\mu}} \\
& =\frac{E / l_{i} \cdot x / L_{i}}{1+\left(l_{k} / l_{i}\right)^{2} \cdot L_{i} / L_{k}} \equiv K_{\mathbf{1}}>0
\end{aligned}
$$

同様に， $\mu=1$ とすれば，

$$
\begin{aligned}
\left.\frac{\Delta T_{k}}{\Delta x}(\mu)\right|_{\mu=1} & =\frac{A_{\mu} \cdot \exp (\theta+\varphi)+B_{\mu}}{1+C_{\mu} \cdot \exp (\theta+\varphi)} \\
& \fallingdotseq \frac{A_{\mu}}{C_{\mu}}=\frac{E / l_{i} \cdot x / L_{i}}{\left(l_{k} / l_{i}\right)^{2} \cdot L_{i} / L_{k}} \equiv K_{\mathbf{2}}>0
\end{aligned}
$$

したがって， $\mu$ に対する $\Delta T_{k} / \Delta x(\mu)$ の変化を図示す ると第 8 図のようになる．結局，R B 現象による編成張 力の低下の度合は, 系の摩擦係数が大きいほど大きくな る.また，前述のように， $\Delta l / \Delta x(\mu)$ 6第 8 図と同じ 変化をする. これは一見, 奇異に感じられるが, Knapton らの実験結果から，乙の推論が正しいととが裏づけ

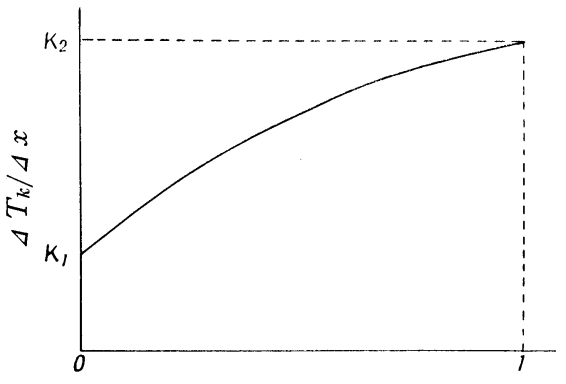

摩擦係数

（第 8 図）摩擦係数に対する $\Delta T_{k} / \Delta x$ の変化

される，第 9 図は，彼らの報告から，ワクシング系と非 ワクシング系を用い給系張力 $2 \mathrm{~g}$ で編成した編地のルー プ長をカムセットに対しプロットしたものであり，各 カムセットにおいて，ワクシングしていない(摩擦係数 の大きい）糸のほうが，約 0.022 in 短くなっている.

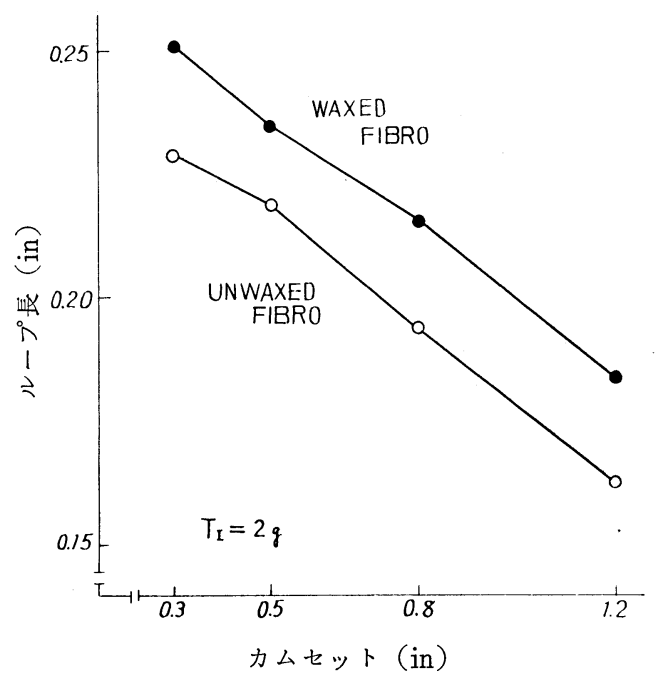

（第 9 図）摩擦係数の異なる糸でのループ長の相違 (J. J. F. Knapton ら)

しかしながら，一般には，摩擦係数は（2）式で示し たように，張力と曲率の関数であるから，上に考察した ことは，でく限られた範囲にのみ成り立つあのと考えら れる。

\section{4. 実験による考察}

\section{1 モデル装置での実験}

実験装置と方法

編成動作を机上で再現するために，第10図に示すモ デル装置を試作した. シンカー $S_{1}, S_{2}$ は背板 $A$ に固定 され（その距離 $G$ は可変）針 $N$ はブラケットBで支持さ れた上下可動の軸 $R$ に固定されている. 同期モータ一か 


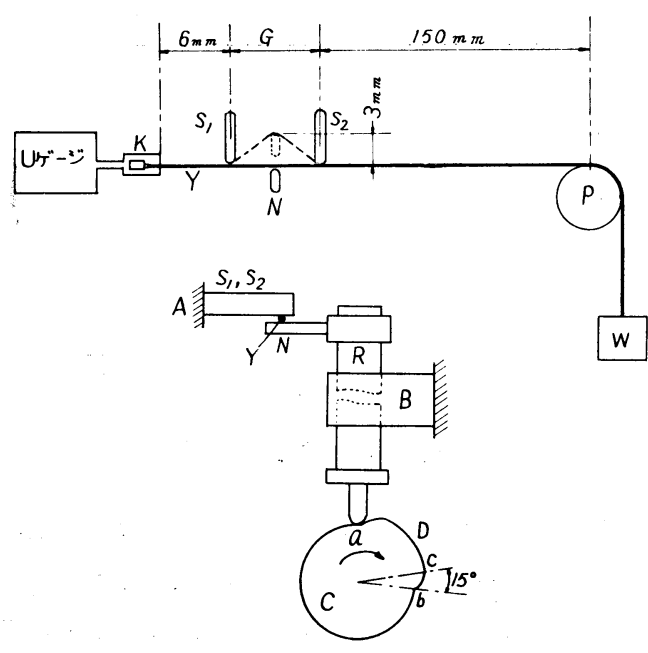

（第 10 図）モデル装置説明図

ら歯車列をへて突起カム $C$ が回転駆動されると, その突 起 $D$ により軸 $R$ が突き上げられ, シンカー $S$ と針 $N$ の間に糸 $Y$ が供給されている場合には, そこで編成動 作に準じた糸の折り曲げが行なわれる．突起 $D$ の立ち 上り部分 $b c$ 間の形状は, 針 $N$ が等速運動する形に作 られており, その中心角は $15^{\circ}$, 立ち上り高さ $3 \mathrm{~mm}$ ある. また, シンカーと針の断面円形部の直径はともに $0.8 \mathrm{~mm}$ である.

一端に荷重 $W$ を吊した糸 $Y$ を, ベアリングで支持し た軸に取り付けたプーリーPに掛け, シンカーと針の間 を通して他端を U ゲージのクランプ $K$ で把持する.

編成動作による糸張力の変化は, U ゲージから動歪 計, 増幅器をへて直記式電磁オシログラフ（振動子の感 度一様の上限振動数 $1000 \mathrm{c} / \mathrm{sec}$ ) により記録した. 測 定に際して, カ厶を軸 $R$ が $a$ 点に接する位置にとった のち同期モーターを駆動し, 助走距離 $a b$ を経たあとの 1 回目の編成動作における記録から,そのピーク值を読 みとり編成張力とした。

試料には, 梳毛系 $2 / 40 \mathrm{~s}$, ウーリーナイロン系 $110 / 2$ $\mathrm{d}$ (第 1 表*印) を用い,つぎの条件で測定した。

$$
\text { ゲージ } G(\mathrm{~mm}) \quad: 3,6,12
$$

初 荷 重 $W(\mathrm{~g}) \quad: 2,6,10,15,20$

編成速度 $V(\mathrm{~cm} / \mathrm{sec}): 5,10,17,25,50$

なお，編成速度は歯車比をかえた測定の記録結果から 算出した.

結果と考察

編成速度 $50 \mathrm{~cm} / \mathrm{sec}$ ，ゲージ $3 \mathrm{~mm}$ で行なった実験に 步时学各給系張力 (初荷重) に対する編成張力の変化を 第11図に示す．両試料とむに，“給系張力が増すにつれ

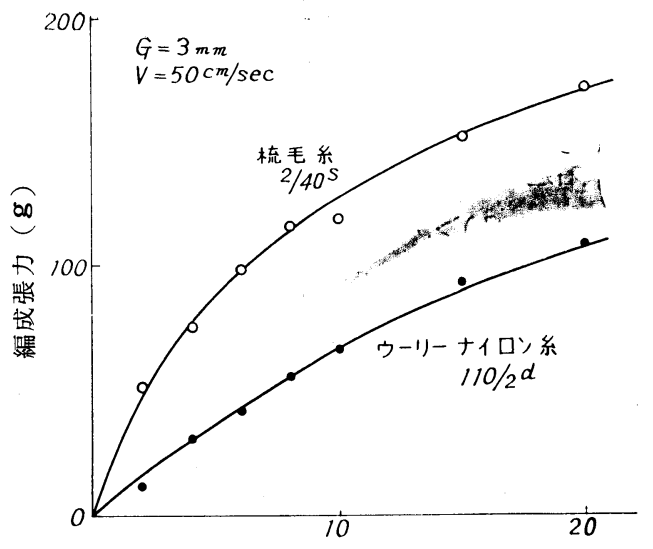

給糸張力 $(\mathbf{g})$

（第11 図）モデル装置による実験

て編成張力も増加するが, その変化は直線的でなく, 給 糸張力の低い範囲で変化の度合が大きくなっている. 第 12 図は, ゲージを変え, カ厶を手動（編成速度 $0.5 \mathrm{~cm}$ /sec以下) により動かした場合の給糸張力と編成張力の 比 $T_{k} / T_{I}$ を給系張力 $T_{I}$ に対しプロットしたあのであ る. 梳毛系では $T_{I}=2 g$ でとくに比 $T_{k} / T_{I}$ が大きく, $T_{I} \geqq 10 \mathrm{~g}$ においては，ほぼ一定值をとる. ウーリーナ イロン系であ同様な関係を示しているが， $T_{I}=2 \mathrm{~g}$ にお ける比 $T_{k} / T_{I}$ は梳毛系の場合のように大きくはない. これは, ウーリー加工によるクリンプが伸びきらずかな り残っているために, 接触面の状態が異なるためと考え られる。

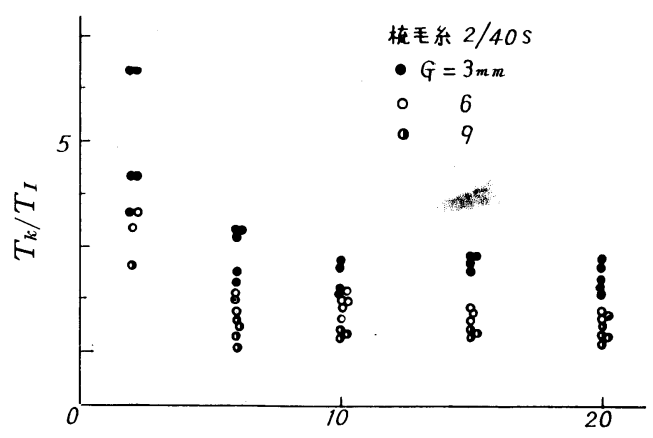

給系張力 $(\mathbf{g})$

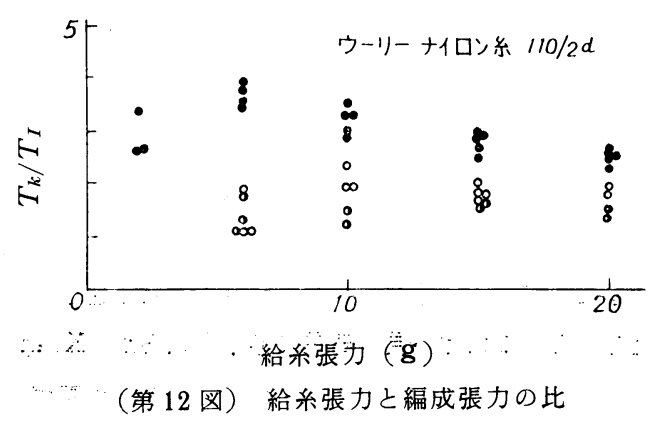


各給系張力に対する比 $T_{k} / T_{I}$ の関係は, ゲージの変 化, つまり接触角が変わってあ同様な関係を示すことか ら, $T_{I}$ に対する $T_{k} / T_{I}$ の変化は摩擦係数の变化を示 すむのと考えられる.したがって, 給系張力の低い範囲 (梳毛系では $6 \mathrm{~g}$ 以下)に扔いては, 摩擦による付加張力 は前記（2）式に基づいて考えるべきてとを示すむので ある. また, $T_{k} / T_{I}$ は, 第 12 図では梳毛系よりもウー リーナイロン系のほうが大きいにもかかわらず，第11 図では梳毛系のほうが大きくなっている，てれから, 編 成張力には編成速度む影響するすのと考えられる。

第 13 図は,ゲージ $3 \mathrm{~mm}$ に扔いて編成速度に対する 編成張力の変化を, 各給糸張力につきプロットしたもの である. な报, 編成速度 0 に打ける值は, カムの回転を 手動で行なった場合の值である.
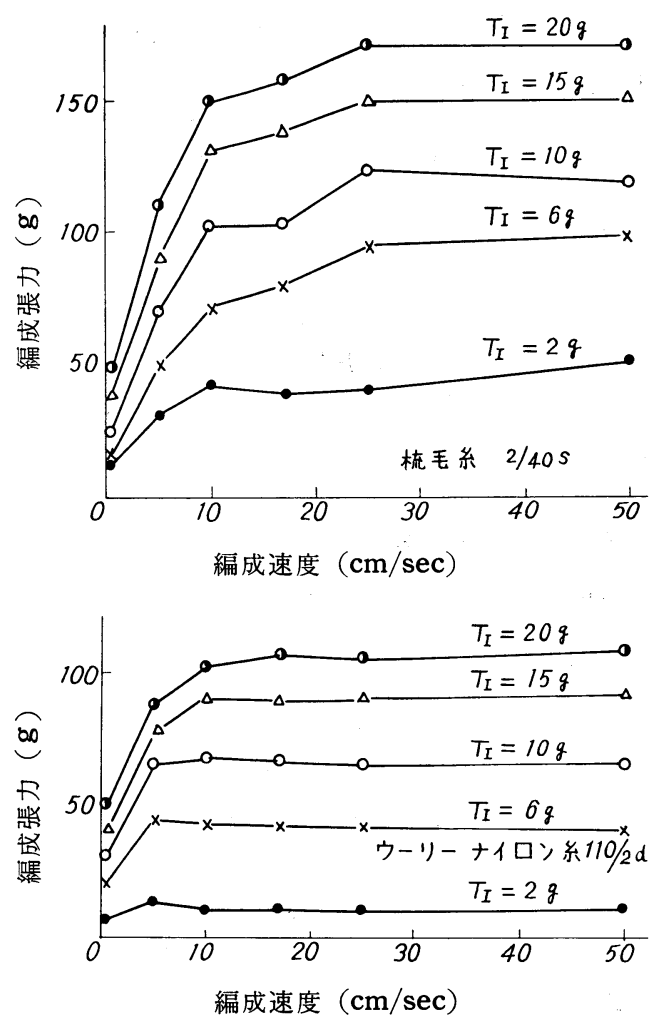

（第13図）編成速度と編成張力の関係

編成速度 $10 \mathrm{~cm} / \mathrm{sec}$ 以下においては, 梳毛系, ウーリ 一ナイロン系ともに, 速度の増加に伴って編成張力む大 きくなるが，それ以上の速度ではほとんど変化がみられ ない. 編成動作の進行に伴って編成張力が増加すると, 給系側から糸が流入し, 張力の増加を抑制するが, 編成 動作が速くなると系の流入量が少なくなり（伸長速度〉 流入速度）乙のために編成張力が大きくなるあのと考え
られる. 梳毛系とウーリーナイロン系との編成張力の 差は系の伸長特悱:の忛違によるものであろう. また, 編 成速度 $10 \mathrm{~cm} / \mathrm{sec}$ 以上において編成張力が一定である ことは, その速度範囲では; 系の引き込み力の編成張力 への影響は少ないととを意味し, 摩擦力と糸の伸長特性 によって編成張力が相違するものと考元られる.

\section{2 丸編機での実験}

\section{実験装置と方法}

使用した編機はシリンダー直径 $20 \mathrm{in}$, 針間隔 $12 \mathrm{npi}$ の台丸編機であり, 回転数 $3 \mathrm{rpm}$ (編成速度 $8 \mathrm{~cm} / \mathrm{sec}$ ) 給糸口 1 ロで実験した。給系張力は, 給系路途中にコイ ル バネで加圧される平行板形張力器をとりつけ, バネ 力を調節して給系口前の測定位置で 1 13 g の範囲にと った。編成張力の測定は, 既報の検出器を用い, そのカ バーを取り替えるととにより, 踏の長さを $2 \sim 5$ 本踏と した. な拀，本編機の標準力ムは 2 本踏CF 1 である. 実験結果と考察

各カムを用いカム セット $h=2.9 \mathrm{~mm}$ で行なった奉 験結果から求めた給系張力一編成張力曲線, 給系張力一 ループ長曲線 および編成張力ーループ長曲線を第 14 図 亿示す。

カムCF 4 亿扔ける給系張力一編成張力曲線は, 第 11 図と似た変化をしており，ループ長むほとんど一定 であることから，てのカムにおいてはRB現象は起てっ ていないと考えられる. 第 14 図に打河る各線図から， カム CF 1 においては， R B 現象による影響が編成張 力, ループ長にあらわれているととが明らかである.

カム $C F 1$ とCF 4 を用いた編成における $\mathrm{R} \mathrm{B}$ 琴象 の有無から, 給系張力一編成張力線図において各給系張 力 $T_{I}$ に対するカム $C F 4$ とCF1 における編成張力 $F_{k 4}$ と $F_{k 1}$ の差は, R B 現象によって生じた糸張力の低 下を, また, 編成張力一ループ長線図におけるループ長 $L_{4}$ と $L_{1}$ の差は R B 現象によるループ長の減少を示す あのと考えられるから，てれらをそれぞれ引き戻し張力 $f_{r}$, 引き戻し系長 $l_{r}$ と呼ぶととにする. すなわち

$$
\begin{aligned}
& f_{r}=F_{k_{\mathbf{4}}}\left(T_{I}\right)-F_{k_{1}}\left(T_{I}\right) \\
& l_{r}=L_{\mathbf{4}}\left\{F_{k_{\mathbf{1}}}\left(T_{I}\right)\right\}-L_{\mathbf{1}}\left\{F_{k_{\mathbf{1}}}\left(T_{I}\right)\right\}
\end{aligned}
$$

また, $f_{r} ・ l_{r}$ は R B 現象によって消費された（ループ 形成に際して節約された）仕事量の意味を持つから，乙 れを引き戻し仕事量 $W_{r}$ と呼ぶことにする，すなわち

$$
W_{r}=f_{r} \cdot l_{r}
$$

(39)〜(41) 式は, 給系張力“荤I儿ついて求まるが,

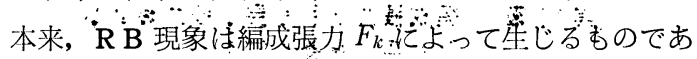




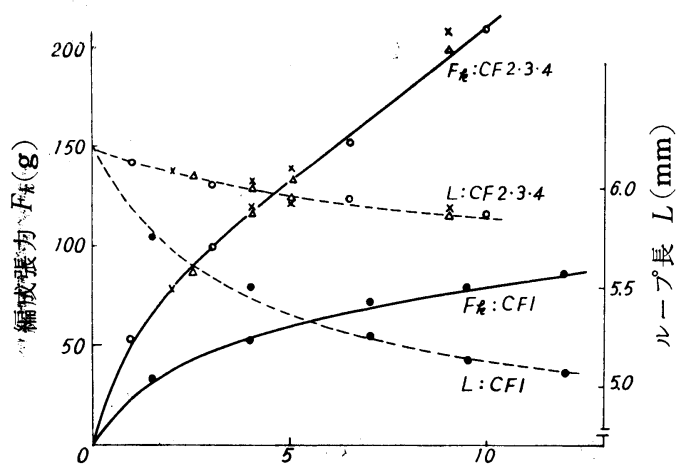

給糸張力 $(\mathrm{g})$

14-1 図梳毛系 $2 / 40 \mathrm{~s}$

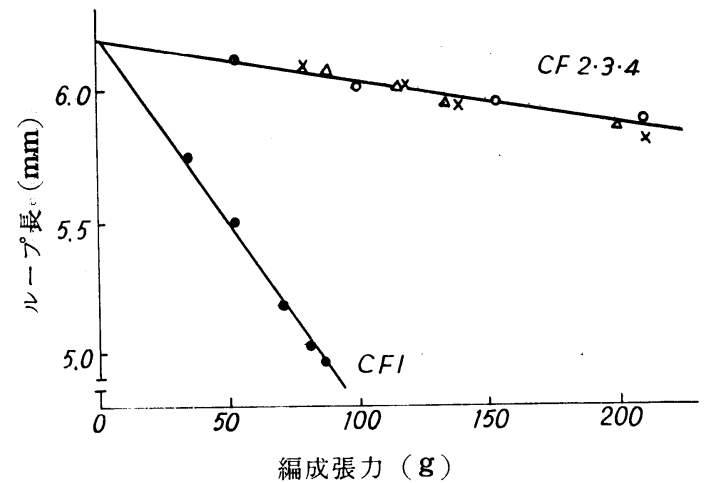

14-2図梳毛系 $2 / 40 \mathrm{~s}$

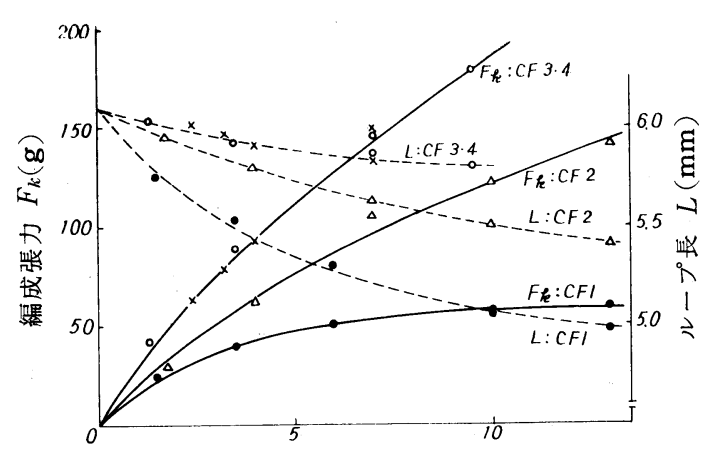

給系張力 $(\mathrm{g})$

14-3 困 ウーリーナイロン系 $[10 / 2 \mathrm{~d}$

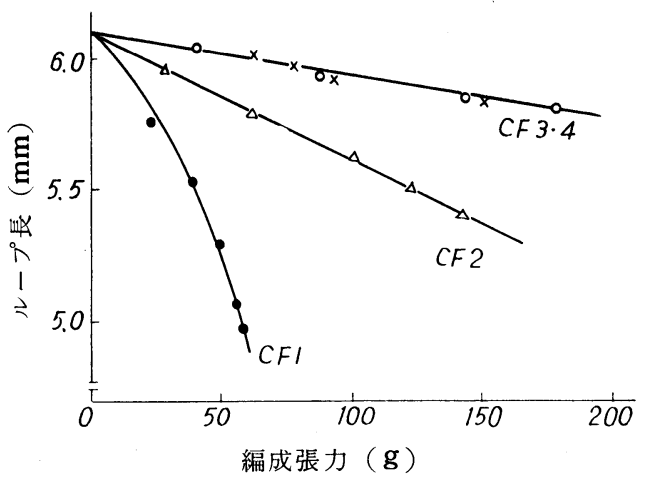

14-4図ウーリーナイロン系 110/2 d

（第 14 図）丸編機での実験結果

るから，橴準力ムCF1における編成張力 $F_{k 1}$ について 調べるほうが適している，第 15 図は, ウーリーナイロ ン系を用いカムセットを 3 段階にとった実験から求めた 引き戻し張力 $f_{r}$ と引き戻し系長 $l_{r}$ の変化の様子を, ま

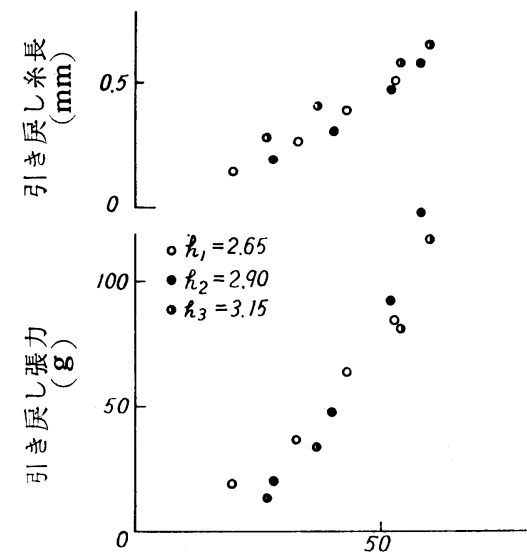

編成張力 $(\mathbf{g})$

（第 15 図）編成張力と引き戻し張力および 引き麽し系長の関係
た，第 16 図は，梳毛系とウーリーナイロン糸の引き戻 し仕事量 $W_{r}$ の変化を示したものである.

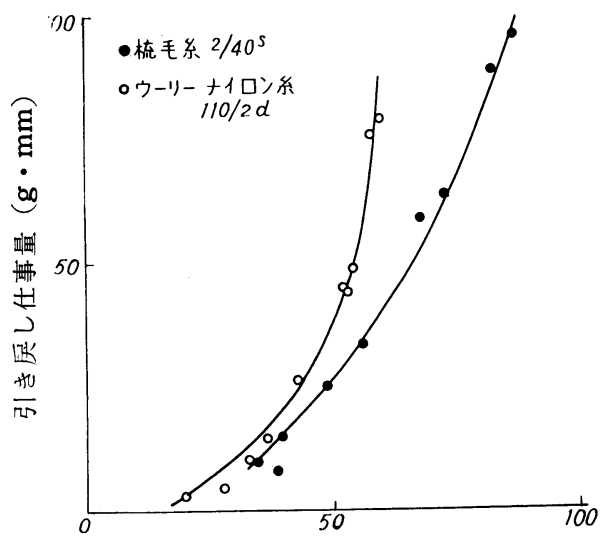

編成張力 $(\mathrm{g})$

（第 16 図） 編成張力と引き戻し仕事量の関係

第 15 図から， $f_{r}, l_{r}$ とあに編成張力が大きくなるに つれて増加するととがわかる，梳毛系においてあ同様な 変化が認められたが， 3 章で考察した摩擦係数，引張弾 
（第 1 表） 原 系 の 性 能

\begin{tabular}{|c|c|c|c|c|c|c|c|}
\hline \multicolumn{2}{|c|}{ 原 } & \multirow{2}{*}{ 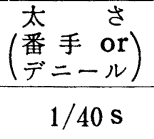 } & \multirow{2}{*}{ 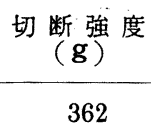 } & \multirow{2}{*}{ 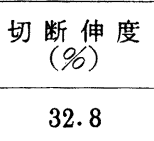 } & \multirow{2}{*}{$\frac{{ }_{E}^{\text {弾 性 係 数 }}}{5580}$} & \multirow{2}{*}{$\frac{T_{0} / T_{I}^{\text {摩 }}\left(\begin{array}{c}\text { 指 } \\
\text { 数 }\end{array}\right.}{1.65}$} & \multirow{2}{*}{$\frac{\begin{array}{c}\text { 曲 代剛 性度 } \\
G\left(\times 10^{-3} \mathrm{~g} \cdot \mathrm{cm}^{2}\right)\end{array}}{4.78}$} \\
\hline 梳 & 采 & & & & & & \\
\hline 毛, & アクリル混紡禾 & $1 / 36 \mathrm{~s}$ & 364 & 23.8 & 6100 & 1.69 & 5.76 \\
\hline & $"$ & $2 / 48 \mathrm{~s}$ & 414 & 30.0 & 5870 & 1.74 & 8.56 \\
\hline 梳 & 米 $*$ ) & $2 / 40 \mathrm{~s}$ & 342 & 24.0 & 7620 & 1.66 & 8.68 \\
\hline & $"$ & $2 / 32 \mathrm{~s}$ & 376 & 21.0 & 6920 & 1.78 & 12.4 \\
\hline ウー & リーナイロン糸 & $100 \mathrm{~d}$ & 520 & 38.0 & 1550 & 1.65 & 1.47 \\
\hline & " & $70 / 2 \mathrm{~d}$ & 428 & 22.4 & 1880 & 1.69 & 1.35 \\
\hline & *) & $110 / 2 \mathrm{~d}$ & 876 & 38.8 & 2580 & 1.70 & 2.71 \\
\hline
\end{tabular}

性係数の差による相違はあまり顕著ではなかった。これ は張力の低下と系の引き戻しが独立して起こるのではな いためと，踏をはずれた針の垂直移動量が相違している ためであろう.

ところで，第 16 図にみるように，引き戻し仕事量 $W_{r}$ の変化は，梳毛系とウーリーナイロン系とで明らかに 異なった変化を示し，さらに，カムセットが異なって む，それぞれの系で同じ曲線上に実験值がのっている。 つまり, 編成張力一引き戻し仕事量曲線は系の物性値の 相違を示すものと考えられる. 第 1 表に示す各メリヤス 用原系を用いて得た結果を第 17 四に示す。

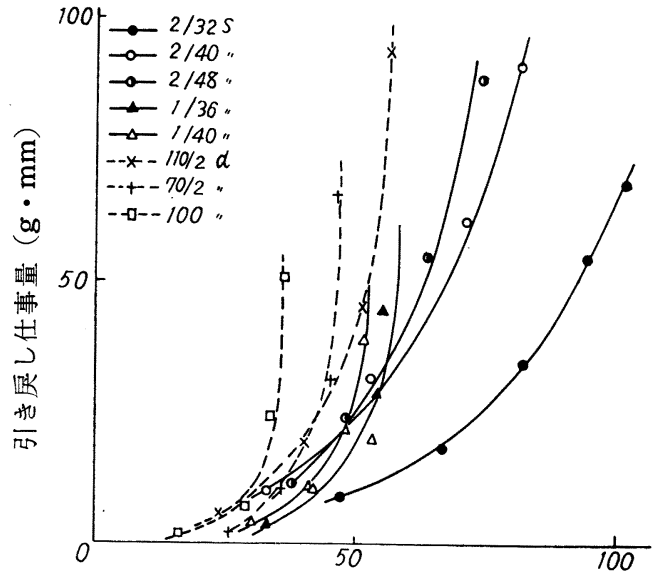

編成張力 $(\mathrm{g})$

（第 17 図）編成張力と引き杘し仕事量の関係

引き戻し仕事量は, 編成張力の增加に伴って大きくな るが, 引張弾性係数 $E$ の小さなウーリーナイロン系で は編成張力のある値から急に大きくなるが，Eの大きな 紡績双系では急激な変化点がみられない, また, 紡績単 系の $E$ は紡績双系の值とさほど違わないのに, 引き戻し 仕事量の変化はウーリーナイロン系のそれ似ており, これらの変化の相違を系の弾性係数あるいは摩擦係数の
差で説明することは困難である.

第 18 図は，編成張力の值を系の太さに対してプロッ トした図で，乙れから太さに関連した物性値が関与して

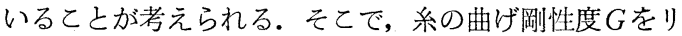
ング法で測定し， $G$ と $F_{k}$ の関係を示したのが第 19 図 である（図中，カッコ内の点はウーリーナイロン). こ れから, 編成張力およびループ長の変化には, 系の曲げ

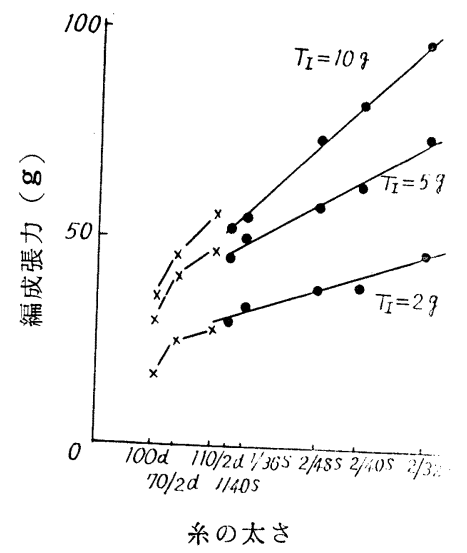

（第18図）系の太さと編成張力の関係

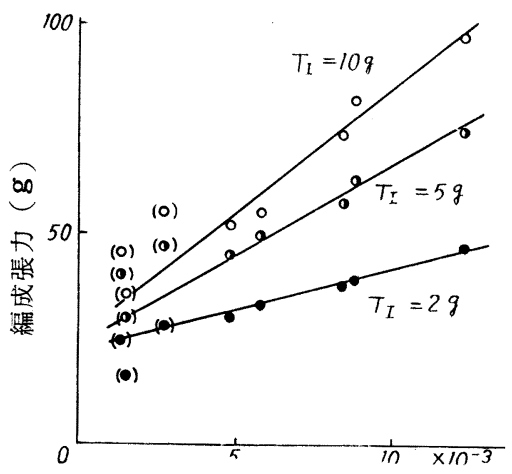

曲げ腩性度 $\left(\mathrm{g} \cdot \mathrm{cm}^{2}\right)$

（リング法）

（第 19 因）系の曲げ剛性度と編成張力の夙 
剛性が寄与しているあのと考えられる，つまり，系張力 の低い範囲においては, 張力の変化は主に系の曲げに関 係し, 高い範囲では系の移動が変化の主体になるもの之 考えられる. したがって, 系屈曲部の弾塑性域の割合, 編成要素間での届曲状態，接触角など，より多くの検討 が必要であろう。

\section{5.むむび}

本報では，系を弾塑性体として扱い，編成張力は編成 要素によるしごき作用によって付加された摩擦力として 解析したが，もとより，編成域中での系の状態変化はか なり複雑であり,さらにR B 現象の生起は解析を困難に する大きな原因である．しかしながら，いくつかの仮定 を置いて導いた（6)，(18）式および（26），(27）式に より, 編成張力およびループ長の変化が定性的に調べら れることが確認された。 また， R B 現象による張力低下 は，切断強力の低い系の編成を可能とすることから，そ の有効利用（カム道の設計など）を積極的に取り上げる ことは，編成能率向上に有意であると考える.

終わりに, 種々ご指導いただいた東京工業大学 不川 章一教授，久世栄一助教授，また，で検討いただいた織
維機械学会メリヤス研究委員会 田畑委員長はじめ委員 各位に深謝する，なお，本報の一部は編成張力と製品の 品質, 物性に関するシンポジゥム（1968-8）において発 表した。

\section{文献}

1）相坂, 川上, 新藤; 緘学誌, 24, 70 (1968)

2) J. J. F. Knapton; Text. Res. J., 37, 539 (1967); 38, 22 (1968)

3 ) D. E. Henshaw; Text. Res. J., 38, 592 (1968)

4) W. N. Garbaruk; Deutsch. Textiltech., 17, 680 (1967)

5）たとえば, T. S. Nutting；J. Text. Inst., 51, T190 (1960)

J. J. F. Knapton, D. L. Munden; Text. Res. J., 36, 1081 (1966); 38, 22 (1968)

6 ) H. G. Howell; J. Text. Inst., 44, T359 (1953)

7 ) C. Rubenstein; Shirley Inst. Mem., 30, 80 (1957); 30, 157 (1957)

8 ）たとえば, 山田，中原；塑性学，P119，1960， 日本機械学会

9 ) J. J. F. Knapton, D. L. Munden; Text. Res. J., 36, 1081 (1966)

10）相坂, 川上, 新藤; 㵶学誌, 24,76 (1968)

注 1 ）既報においては, 給系張力一編成張力曲線を直線 近似した。 